\title{
The new talents and the hierarchy of values at the workplace: a survey with higher education students of health and entrepreneurial management
}

\section{Los nuevos talentos y la jerarquía de valores en el trabajo: una encuesta a estudiantes de educación superior de gestión de la salud y emprendimiento}

\author{
MOREIRA, Sandra M. ${ }^{1}$ \\ MONTANARI, Robson L. ${ }^{2}$
}

\begin{abstract}
The present study aimed to identify the hierarchy of work values from higher education students in the areas of health and business management. The study used the Labor Values Scale (LVS), from Porto and Tamayo (2003) as a research and diagnostic tool. The study sample consisted of 335 students from a private college from the areas of health and business, aged over 17 years. The results show that the priority of values begins with stability, followed by fulfilment at work.

key words: personal values, work values; evt scale, hierarchy of values.

Resumén

Este estudio tiene como objetivo identificar la jerarquía de valores laborales de los estudiantes de educación superior en las áreas de salud y gestión empresarial. El estudio utilizó la Escala de Valores Laborales (EVL), de Porto y Tamayo (2003) como herramienta de diagnóstico. La muestra contenía 335 estudiantes de una facultad privada de las áreas de salud y negocios, mayores de 17 años. Los resultados muestran que la prioridad de valor comienza con la estabilidad, seguida de la realización laboral.

Palabras clave: valores personales, valores laborales; escala evl, jerarquía de valores
\end{abstract}

\section{Introduction}

The term "competitiveness", so common in the entrepreneurial environment, expects organizations to quickly adapt to changes, consequently leading to alterations in the working environment, which demands talented people who are compatible with this rhythm.

Brazil aims at developing or train its talents through financial resources from fostering agencies, for example, scholarships. Consistent with this reality, there was an increase in Brazilian investments for the qualification of young talents, the proof of this being the great increase in the number of scholarships for postgraduate studies in Brazil and abroad. In general, investments by the Coordination for the Improvement of Higher Education Personnel (CAPES) in scholarships grew 159.48\% between 2002 and 2012 (Lievore Et al., 2017). Scholarships for

\footnotetext{
${ }^{1}$ Mestre em Engenharia da Produção pela Universidade Tecnológica Federal do Paraná (UTFPR), Especialista em Administração de Recursos Humanos (UNIVEL), Especialista em Gestão Estratégica de Organizações (UNISEP), Graduada em Administração (UNICENTRO). É professora em cursos de graduação e pós graduação e consultora empresarial na área de Gestão de Pessoas. Email: sandrammoreira77@gmail.com

2 Mestre em Engenharia da Produção e Especialista em Gestão Industrial com ênfase em Conhecimento e Inovação pela Universidade Tecnológica Federal do Paraná (UTFPR) e Especialista em Gestão Estratégica de Pessoas e Negócios pela Fae Business School. É professor em cursos de graduação e pós graduação e consultor empresarial na área de Gestão de Pessoas com expertise em Liderança e Desenvolvimento de Equipes no ambiente produtivo. Email: prof_robson@terra.com.br
} 
postgraduate international studies grew 178\% between 1998 and 2012. "International studies contribute uniquely with highly qualified training, with the skills and abilities necessary for the advancement of national knowledge in partnership with renowned international institutions" (Lievore Et al., 2017).

The necessity to manage HR departments adequately has proven the key aspect for today's organizational survival. Nevertheless, in the modern corporative environment, leading talents in search of results is no guarantee for a strategic differential, even when counting with the best talents of the field. Understanding the mechanisms which operate alongside these young talents in the workplace turns out to be crucial in search of the best results.

The work in today's society, which operates in the generation of social relations, favouring the satisfaction of individual necessities, has caused new demands in the scientific and corporative environments, which are associated to the different senses or values in the workplace, that directly influence the satisfaction of the employees.

The first discussions concerning the values in the workplace were conducted by Rokeach (1973), as stated by Pasquali and Alves (2004). The value concept was highlighted in the 1990's with the study of Schwartz (1992) about individual values. The differences and similarities in work value in relation to different national cultures were studied by Latifi (2006); Gahan and Abeysekera (2009) recently, new research about the topic Góes (2006); Estivalete Et al. (2009) and Almeida Et al. (2015) - point out the necessity of aligning the work values to the strategic management of the organization.

The need for a better entrepreneurial performance and the new current human resources have worried professionals from the personnel management department, who need to coexist and understand hierarchical differences in professional values and the distinct motivational priorities or values.

Considering that personal values influence the search for a job, as Tamayo Et al. (1998) forebode, and taking into account that there have been significant changes in values related to demographic factors such as gender, age and level of education, as concluded by Rokeach (1974) and Hirschi (2010), the hypotheses of the current study have been defined: 1) The professional fields prioritize values related to work differently, and 2) Variables such as age, work experience, gender, marital status and salary influence the hierarchy of values in the workplace.

This study aims to identify the hierarchy of values in the workplace of young college students in the fields of health and corporate management. The hypotheses were put to test by understanding the existing relationships between the factors of the instrument Scale of Values Relating to Labor (original: Escala de Valores do Trabalho "EVT", our translation), coined by Porto and Tamayo (2003), and the different public profiles,

\subsection{Personal values}

The topic of personal values has sparked the interest besides the field of social psychology. According to Tamayo (2007), the topic of values contains three distinct dimensions: personal values, work values and organizational values. In Rohan's (200, p.256) vision personal values can be translated to the following expression "to confer value to something or someone" (our translation). Reis Et al. (2010) confirm that values are present in each aspect of the life of everyone, and consider that personal values emerge before professional values. In Porto's (1998) opinion, these values sustain the pillars of organizational culture and express the possible behaviors in the organization. In practical terms, the different researches which thematise value do not keep one line of discussion between the authors.

Rokeach (1973), Schwartz and Bilsky (1987), Schwartz (1992), Porto and Tamayo (2003) and Ros (2006) advocate that the values are related to beliefs and desirable behaviors which orientate decisions on attitudes, situations, 
and people by determining their importance. Schwartz (2011) affirms that value influence the performance which determines a person's conduct throughout their lives.

The vision of values, associated with goals or ambitions, are discussed by Rokeach (1973); Schwartz (2006) and Knafo Et al. (2011). Nonetheless, an alternative array is presented by Lewi (1952) apud Rohan (2000), inferring that values are not goals, that the individual does not try to achieve them, but rather are considered the driving force of one's decisions, thus can be regarded as guides of one's behavior.

In Rokeach's (1973) framework, values involve judgments of what is right or wrong, adequate in a certain situation or desirable, which allows to foresee the tendency of actions and control one's decisions. Similar notions to the ones from Rokeach (1973) are shared by Porto and Tamayo (2003) and Pasquali and Alves (2004), who point out that people give value to something according to their priorities of values, which are then organized in a hierarchy of values.

"Some people are able to identify their principles in a responsible manner, however some values within people might not manifest themselves in certain daily situations, but only emerge in a certain specific situation." (Calvosa, 2012, p.6 our translation). According to Rokeach (1973), the context and the surrounding in which the person finds themselves influence their judgement about what is considered desirable. Situations which go through collective changes might impact prioritization of one's values.

Ros (2006) punctuates that the values seem to be associated to various factors such as contact between groups, cooperation, politics, environmental actions, law performance and the methods used to solve conflicts. In Kanfo Et al. (2011) opinion everyone owns a personal value system, because of their social experience with the agents that influenced their lives- their family atmosphere and cultural surroundings.

Schwartz's (2006) study synthesizes value characteristics that clarify the inclusiveness of the term: 1) a belief; 2) that belongs to the final goals or the type of behavior; 3 ) that transcends the specific situation; 4) that guides the selection or the evaluation of behavior, people and events; and 5) that is organized in terms of value priorities.

In practical terms, inferred to Knafo Et al. (2011), values command the human being, are difficult to understand and reside in an unconscious and very intimate place in the human mind. In Porto and Tamayo's (2007) opinion, value has a very broad nature when aimed at the general context of life or is very specific when directed towards certain contexts such as work, family, and religion.

\subsection{Values in the workplace}

Individual values pursue a crucial role on the importance that people attribute to work (Estivalete Et al., 2009). The understanding of values related to the workplace enables the development of convergent goals with the values of their skills and they can positively influence the search of better results due to the motivation of group work (Porto \& Tamayo, 2008).

Studies forebode a dichotomy between intrinsic and extrinsic values in the workplace. The intrinsic values are generated by rewards of work itself, such as self-accomplishment, self-determination, and the sense of competence. The extrinsic values are linked to material rewards, such as a raise in salary, the opportunity of a promotion and good working conditions (Ros Et al., 1999; Gahan; Abeysekera, 2009; Hirschi, 2010).

For Tamayo and Paschoal (2003), the basic interest of an employee is not to increase the company's profit but rather fulfil their personal needs while considering their values. If these values are not respected, the employee might feel exploited rather than in an exchange. 
The general characteristics of the values can be common to the individual and organizational values, affirm Porto and Tamayo (2008) providing an opportunity to understand the relationship of objectives between the employee and the company. Maccoby (2006) infers that by searching satisfaction in personal goals, which are associated to the company's goals, would cause the work effort to be driven by common desire rather than obligation.

The theory proposed by Schwartz (1992) is the most respected, describing the elements of motivation that influence the values of work, which required validation of the model in the Brazilian culture (Kamia \& Porto, 2011). In order to adapt and measure the construct in the Brazilian reality, Porto and Tamayo (2003) deepened the theories and also grouped the concepts by Ros, Schwartz and Surkiss (1999) concerning theory of labor values, proposing, testing and validating a suitable instrument to the Brazilian reality, Scale of Values Relating to Labor, EVT “Escala de Valores Relativos ao Trabalho" (Calvosa, 2012)

For Porto and Tamayo (2003) the EVT evaluates principles or beliefs about goals or rewards that are hierarchically organized, that people seek through work and which guide their evaluations of results and the work context. The Scale of Values Relating to Labor (EVT) of Porto and Tamayo (2003, p.151) is composed of 4 factors:

A) Achievement in the workplace: composed by enjoying work, acting with creativity, autonomy of thought, personal and professional fulfilment;

B) Social relations: when the individual seeks positive relationships at work and collaboration with the community where he lives through work;

C) Prestige: seeking professional success, status, fame, authority and power of influence at work;

D) Stability: prioritizing the search for security he wants to have order in personal and professional life through work; meeting individual needs with material goods;

The Scale of Values Relating to Labour (EVT) of Porto and Tamayo (2003) is used in the present study to test the hypotheses and to enable an understanding of the priorities of values in the workplace.

\section{Methodology}

The methodological procedures that guided the present study are presented by Gil (2008) as a survey and were adapted to the research.

The data universe covers young students of higher education in the courses of Administration, Accounting, Pharmacy and Physiotherapy of a private college, located in the Southwest of Paraná, with a total of 402 students. The sample comprised 335 students and was defined according to the guidelines of Triola (1999):

Figure 1

Calculation formula for demonstration

\begin{tabular}{|c|c|}
\hline & Where: \\
\hline $\mathrm{n}=\mathrm{N}$ & $\mathbf{n}$ : is the number of elements of the sample (sample size); \\
\hline $1+\mathrm{Nx} \mathrm{d}^{2}$ & $\begin{array}{l}\text { N: number of the elements or the population lsize or the } \\
\text { population); }\end{array}$ \\
\hline$Z^{2} \times p \times q$ & $\begin{array}{l}\text { Z: is the value of the abscissa of the normal curve associated with } \\
\text { the level of confidence; } \\
\mathbf{d} \text { : is the tolerable sample error (sample precision) in percentage; } \\
\mathbf{p} \text { e q: proportion of choosing a given company at random }\end{array}$ \\
\hline
\end{tabular}

Calculation of the sample with the purpose of obtaining a confidence level of $95 \%$, using the Critical Value $Z=1,96$; Sample error (d) of $4 \%$; $P$ and $q=0.5$.

Source: Triola (1999, p. 410). 
To calculate the sample with the purpose of obtaining a confidence level of $95 \%$, the Critical Value $Z=1.96$ was used; Sample error ( $d$ ) of $4 \% ; p$ and $q=0.5$. Chart 1 shows the number of participants of each researched course:

Table 1

Population $\mathrm{x}$ sample

\begin{tabular}{c|c|c}
\hline Courses & Population & Sample \\
\hline Administration & 120 & 100 \\
Accounting sciences & 168 & 131 \\
Pharmacy & 45 & 42 \\
Physiotherapy & 69 & 62 \\
Total & 402 & 335 \\
\hline \multicolumn{2}{|c}{ Source: Own authors (2018) }
\end{tabular}

The study aimed to present a sample with a high degree of confidence (95\%). According to Michalski and Kaufman apud Santos Et al. (2017) the effectiveness of the method depends on the rigor of this process and all its stages, including the high degree of confidence in the sample, are important for the final product.

The participants of each course were chosen at random, indicating only the course and period for assignment. The data collection was performed by the authors, in the period of october 2018, ouctober 2018, distributing the self-explanatory questionnaires, informing the research objective, and ensuring the anonymity of the respondents. The voluntary nature of participation in the research has also been clarified, and only those who agreed with these terms answered the questionnaire. The questionnaires were returned directly to the researchers who waited for their completion.

The form used for data collection was constructed and validated with the EVT of Porto and Tamayo (2003). The construct showed Cronbach's alpha greater than 0.8 in all categories. For Cronbach and Meehl (1995) apud Pedroso Et al. (2014a), Cronbach's alpha result equal to or greater than 0.7 is consistent and can be used in research and diagnostics.

According to Porto and Tamayo (2003, p.151, our translation) the study "contributes significantly to the understanding of the motivations for work and to the development of research on consequent values related to work such as the choices for work alternatives."

According to Porto and Tamayo (2008), to calculate the order of values relative to the individual's work, one must first calculate the average of each category of values. The instrument is composed of 45 items, divided into four categories described in Table 2:

\section{Table 2}

Categories of the instrument of EVT

\begin{tabular}{|l|l|l|}
\hline Factor & Denominations & Definitions \\
\hline 1 & $\begin{array}{l}\text { Fulfillment in } \\
\text { the workplace }\end{array}$ & $\begin{array}{l}\text { Search for pleasure and personal and professional } \\
\text { fulfillment, as well as independence of thought and action } \\
\text { at work through intellectual autonomy and creativity; }\end{array}$ \\
\hline 2 & Social relations & $\begin{array}{l}\text { Search for positive social relationships at work and positive } \\
\text { contributions to society through work; }\end{array}$ \\
\hline 3 & Prestige & $\begin{array}{l}\text { Seeking authority, professional success, and power to } \\
\text { influence at work; }\end{array}$ \\
\hline 4 & Stability & $\begin{array}{l}\text { Seeks security and order in life through work, making it } \\
\text { possible to supply materially to personal needs. }\end{array}$ \\
\hline
\end{tabular}

Source: Porto \& Tamayo (2003, p. 151). 
For Porto and Tamayo (2003) the content of each factor properly contemplates its theoretical definition. Table 3 shows the contents that make up each factor of the instrument:

Table 3

Division of each item in factors

\begin{tabular}{|c|c|}
\hline Factor: Fulfillment in the worplace (15 items) & Factor: Social relations (12 items) \\
\hline $\begin{array}{l}\text { 4. Professional performance } \\
\text { 5. Do a meaningful job for me } \\
\text { 7. Intellectually stimulating work } \\
\text { 8. Autonomy to establish the way the work is } \\
\text { performed } \\
\text { 10. Take pleasure in what I do } \\
\text { 12. Personal Satisfaction } \\
\text { 13. Interesting work } \\
\text { 14. Intellectual growth } \\
\text { 16. Like what I do } \\
\text { 24. Identify myself with work } \\
\text { 30. Personal fulfillment } \\
\text { 39. Be happy with the work you do } \\
\text { 40. Assorted work } \\
\text { 41. Improve knowledge of my profession } \\
\text { 44. Work that requires originality and creativity }\end{array}$ & $\begin{array}{l}\text { 3. Fighting social injustices } \\
\text { 11. Meet people } \\
\text { 19. To be useful to society } \\
\text { 20. Assist co-workers } \\
\text { 21. Preserve my health } \\
\text { 23. Good relationship with co-workers } \\
\text { 26. Friendship with co-workers } \\
\text { 28. Have a social commitment } \\
\text { 29. Collaborate for the development of } \\
\text { society } \\
\text { 32. Change the world } \\
\text { 36. Helping others } \\
\text { 45. Collaborate with co-workers to } \\
\text { achieve group work goals }\end{array}$ \\
\hline Factor: Prestige (11 items) & Factor: Stability (7 items) \\
\hline $\begin{array}{l}\text { 6. Competitiveness } \\
\text { 15. Following the family profession } \\
\text { 17. Status at work } \\
\text { 22. Have prestige } \\
\text { 25. Oversee other people } \\
\text { 27. Competing with co-workers to achieve my } \\
\text { professional goals } \\
\text { 31. Have superiority based on the success of my } \\
\text { work } \\
\text { 33. To have fame } \\
\text { 34. To have notoriety } \\
\text { 38. Face challenges } \\
\text { 42. Get featured position }\end{array}$ & $\begin{array}{l}\text { 1. Financial stability } \\
\text { 2. Be financially independent } \\
\text { 9. Being able to support myself } \\
\text { 18. Making Money } \\
\text { 35. Stability at work } \\
\text { 37. Meeting material needs } \\
\text { 43. Have better living conditions }\end{array}$ \\
\hline
\end{tabular}

Source: Porto \& Tamayo (2008, p.302).

The tool makes it possible to assess the importance of each value as a guiding principle in your work life. The higher the number $(1,2,3,4,5)$, the more important is the value in professional life. Using the rating scale shown in Table 4:

Table 4

Measure pattern

\begin{tabular}{|c|c|c|c|c|}
\hline $\begin{array}{c}1 \text { Not } \\
\text { important }\end{array}$ & $\begin{array}{c}\text { 2 Somewhat } \\
\text { important }\end{array}$ & 3 Important & $\begin{array}{c}4 \text { Very } \\
\text { important }\end{array}$ & $\begin{array}{c}5 \text { Extremely } \\
\text { important }\end{array}$ \\
\hline
\end{tabular}

Source: Porto e Tamayo (2008, p. 304).

For Porto and Tamayo (2008, p. 303) in order to calculate the results of each factor, it is possible to "compute the factors in order to identify the most important factors (with the highest average) and the least important ones (with a lower average) for individuals ".

In the data tabulation and analysis of the results, the software SPSS Statistics v.23 (Software Package Used for Statistical Analysis) was used to obtain the means, standard deviation, Kolmogorov-Smirnov normality, 
considering a significance index $p<0.05$ (Santos Et al., 2017) Test of Mann-Whitney hypothesis to verify the difference between the means of the areas, courses, genres, considering significant when $p<0.05$. The reliability test and correlations between the variables age, gender, labor market experience, parental schooling and the factors of the EVT research instrument through correlation (Spearman's p) were used.

\section{Results}

The results initially analyse the profile of the respondents to understand how the results relate to the sociodemographic data of the group. Table 5 shows the sample profile:

Table 5

Sample profile

\begin{tabular}{|c|c|c|c|c|c|}
\hline $\begin{array}{l}\text { Variables and } \\
\text { categories }\end{array}$ & Freq. & $\%$ & Variables and categories & Freq. & $\%$ \\
\hline Gender & & & Marital status & & \\
\hline Female & 238 & 71 & Single & 269 & 80 \\
\hline Male & 97 & 29 & Married & 29 & 9 \\
\hline Age & & & Stable union & 31 & 9 \\
\hline 17 & 8 & 2 & Divorced & 4 & 1 \\
\hline 18 & 33 & 10 & Widowed & 2 & 1 \\
\hline 19 & 46 & 14 & Time present & & \\
\hline 20 & 67 & 20 & In the job Market & & \\
\hline 21 & 49 & 15 & Has never worked & 52 & 16 \\
\hline 22 & 34 & 10 & Up to 1 year & 25 & 7 \\
\hline 23 & 20 & 6 & between 1 and 3 years & 69 & 21 \\
\hline 24 & 18 & 5 & between 3 and 5 years & 57 & 17 \\
\hline 25 & 14 & 4 & More then 5 years & 132 & 39 \\
\hline 26 & 7 & 2 & Family income & & \\
\hline 27 & 4 & 1 & Up to $\mathrm{R} \$ 1576,00$ & 35 & 10 \\
\hline 28 & 6 & 2 & between $\mathrm{R} \$ 1576,01$ and $\mathrm{R} \$ 3152,00$ & 139 & 41 \\
\hline 29 & 7 & 2 & between $R \$ 3152,01$ and $R \$ 7880,00$ & 124 & 37 \\
\hline \multirow[t]{2}{*}{ Over 30} & 22 & 7 & between $\mathrm{R} \$ 7880,01$ and $\mathrm{R} \$ 15.760,00$ & 24 & 7 \\
\hline & & & $\mathrm{R} \$ 15760,01$ or more & 13 & 4 \\
\hline Course & & & Period & & \\
\hline Administration & 100 & 30 & 2 semester & 77 & 23 \\
\hline $\begin{array}{r}\text { Accounting } \\
\text { sciences }\end{array}$ & 131 & 39 & 4 semester & 88 & 26 \\
\hline Pharmacy & 42 & 13 & 6 semester & 90 & 27 \\
\hline Physiotherapy & 62 & 19 & 8 semester & 80 & 24 \\
\hline
\end{tabular}

The profile of the sample indicates that $71 \%$ of the respondents are female, confirming that the majority of Brazilian higher education students are female (Portal Brasil, 2015). The participants are normally aged between 18 and 22 years; The Business courses (Administration and Accounting) represented around $69 \%$ in the sample; The periods are almost equally split between $23 \%$ and $27 \%$; The predominant marital status was single, with $80 \%$. The time period in the labor market was most frequently in 5 years, with $39 \%$ of the sample; $16 \%$ of respondents have never worked. There was a higher concentration of family income was between $\mathrm{R} \$ 1576,01$ and $R \$ 7.880,00$, including the $D$ and $C$ classes, respectively.

Regarding the reliability of the original instrument and the reliability of the results of this research, table 3 presents the number of items in each factor and the reliability indexes (Cronbach's alpha) for the four instrument factors that were originally higher than 0.80 in the research of Porto and Tamayo (2003): 
Table 6

Realiability of the factors

\begin{tabular}{lc|c|c}
\hline Factors & $\begin{array}{c}\text { Number of } \\
\text { Items }\end{array}$ & $\begin{array}{c}\text { Alfa de Cronbach } \\
\text { Original }\end{array}$ & $\begin{array}{c}\text { Alfa de Cronbach } \\
\text { this research }\end{array}$ \\
\hline $\begin{array}{l}\text { Factor 1 - Fulfillment in the } \\
\text { workplace }\end{array}$ & 15 & 0,88 & 0,88 \\
Factor 2 - Social relations & 12 & 0,88 & 0,88 \\
Factor 3 - Prestige & 11 & 0,87 & 0,85 \\
Factor 4 - Stability & 7 & 0,81 & 0,75 \\
Total of values & 45 & - & 0,941 \\
\hline
\end{tabular}

Source: Own authors (2018)

The present research presented reliability index (Cronbach's alpha) for all factors higher than 0.70 , similar to that presented in the original instrument. The literature on the coefficient of Cronbach's alpha suggests that each researcher adopts a cut line to consider the issue consistent or not. According to Cronbach and Meehl (1995) apud Pedroso Et al. (2014a), coefficients equal to or greater than 0.7 are considered acceptable. Observing the results proved to reliable, emphasizing that the 45 values of the pooled instrument present a coefficient (Cronbach's alpha) of 0.941.

Using the precepts of Dancey and Reidy (2006) it was analyzed the classification of the data in normal or nonnormal, the number of cases, the normal distribution of the data, the homogeneous variance and the absence of outliers. Afterwards, the variables were submitted to the Kolmogorov-Smirnov normality test, considering a probability (p) of 0.05 (SANTOS Et al., 2017). The results presented are of non-normal distribution, existence of few extreme cases and normality test for all variables of $p<0.05$. Therefore, non-parametric data tests were chosen.

For a better understanding of the analysis results, the scores classification purposed by Esteves (2008) was employed, in which the results of the EVT can be sorted out, as shown in table 7:

Table 7

Score classification of the EVT instrument

\begin{tabular}{c|c}
\hline Value range & Classification \\
\hline 1 to 2,5 points & Somewhat important \\
2,6 to 3,5 points & Considerable Importance \\
3,6 to 5,0 points & Very important \\
\hline
\end{tabular}

Source: Esteves (2008, p. 73).

The identification of the priority of work values is presented by the students of the 4 top courses of the areas of health and business management in table 8 : 
Table 8

Hierarchy of professional values

\begin{tabular}{|c|c|c|c|c|}
\hline $\begin{array}{c}\text { Descriptive } \\
\text { Statistics }\end{array}$ & $\begin{array}{c}\text { Fulfillment } \\
\text { In the Workplace }\end{array}$ & $\begin{array}{c}\text { Social } \\
\text { Relations }\end{array}$ & Prestige & Stability \\
\hline General Average & 4,04 & 3,72 & 3,19 & 4,33 \\
\hline Standard deviation & 0,566 & 0,688 & 0,732 & 0,547 \\
\hline Medium & 4,07 & 3,75 & 3,27 & 4,43 \\
\hline \multicolumn{5}{|l|}{ Grouping in zones } \\
\hline 1 to 2.5 points & $1 \%$ & $6 \%$ & $23 \%$ & $1 \%$ \\
\hline 2.6 to 3.5 points & $13 \%$ & $36 \%$ & $46 \%$ & $10 \%$ \\
\hline 3.6 to 5.0 points & $85 \%$ & $58 \%$ & $31 \%$ & $89 \%$ \\
\hline
\end{tabular}

Source: Own authors (2018)

The results allowed identifying higher average for the factor stability, 4.33, stating that the group values more strongly security, which is represented by order in life and meet their personal needs. The achievement factor at work, the second highest average, with 4.04, is associated with the search for pleasure in work, creativity, autonomy and intellectual growth. The third factor, social relations, with an average of 3.72, prioritizes the search for good social coexistence and concern for the neighbors and community. The fourth and last factor, prestige, with average of 3.19, demonstrates less importance to success and power of influence.

The prestige factor presented the greatest dispersion of data in relation to the average, with standard deviation 0.732; followed by social relations, 0.688 ; third in dispersion is the achievement factor at work, 0.566 ; and the factor at the top of the stability hierarchy, in addition to the highest average, presented the lowest standard deviation of 0.547 . In general lines, the more important the value, the lower the dispersion.

The results demonstrate coherence with studies by Góes (2006); Estivalete Et al. (2009) and Dias (2012) who used a sample of greater work experience, as shown in Table 9.

Also in table 9, in the grouping of results in the range, one can identify that the first 3 factors of the hierarchy fall into the very important classification and only the prestige factor classified with considerable importance:

Table 9

Comparison with other findings

\begin{tabular}{|c|c|c|c|}
\hline Authors & Results & Averages & Sample \\
\hline Góes (2006) & $\begin{array}{l}\text { Stability } \\
\text { Fulfillment at work } \\
\text { Social relationships } \\
\text { Prestige }\end{array}$ & $\begin{array}{l}4,24 \\
4,01 \\
3,70 \\
2,61 \\
\end{array}$ & $\begin{array}{l}\text { Sample: } 183 \text { employees of } \\
\text { public financial institution of } \\
\text { Brasilia. }\end{array}$ \\
\hline $\begin{array}{l}\text { Campos e Teixeira } \\
\text { (2007) }\end{array}$ & $\begin{array}{l}\text { Fulfillment at work } \\
\text { Stability } \\
\text { Social relationships } \\
\text { Prestige }\end{array}$ & $\begin{array}{l}4,25 \\
3,98 \\
3,69 \\
2,94\end{array}$ & 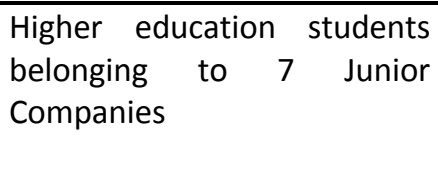 \\
\hline Esteves (2008) & $\begin{array}{l}\text { Fulfillment at work } \\
\text { Stability } \\
\text { Social relationships } \\
\text { Prestige }\end{array}$ & $\begin{array}{l}4,27 \\
4,18 \\
3,82 \\
2,56\end{array}$ & $\begin{array}{ll}\text { Human } & \text { Resources } \\
\text { Professionals } & \end{array}$ \\
\hline $\begin{array}{l}\text { Estivalete Et al. } \\
\text { (2009) }\end{array}$ & $\begin{array}{l}\text { Stability } \\
\text { Social relationships } \\
\text { Fulfillment at work } \\
\text { Prestige }\end{array}$ & $\begin{array}{l}4,01 \\
3,94 \\
3,90 \\
3,28 \\
\end{array}$ & $\begin{array}{l}\text { Sample } 130 \text { employees from } \\
\text { the operational area of an } \\
\text { internationalized refrigerator } \\
\text { company. }\end{array}$ \\
\hline Dias (2012) & $\begin{array}{l}\text { Fulfillment at work } \\
\text { Stability } \\
\text { Social relationships }\end{array}$ & $\begin{array}{l}3,83 \\
3,65 \\
3,58\end{array}$ & $\begin{array}{l}\text { Sample } 157 \text { surveyed early in } \\
\text { career }\end{array}$ \\
\hline
\end{tabular}




\begin{tabular}{|l|l|r|l|}
\hline & Prestige & 2,56 & \\
\cline { 2 - 4 } & Stability & 4,22 & Sample 157 surveyed at the \\
& Fulfillment at work & 4,20 & current time of the road, 53\% \\
& Social relationships & 3,73 & up to 10 years of experience \\
& Prestige & 3,29 & \\
\hline Macedo (2012) & Fulfillment at work & 4,10 & Sample 83 people of \\
& Stability & 4,06 & generation Y and Z, young \\
& Social relationships & 3,50 & people born from 1980. \\
& Prestige & 2,59 & \\
\hline
\end{tabular}

Source: Own authors (2018)

The studies of Campos and Teixeira (2007), Esteves (2008), Dias (2012) with sample of beginning of career; Macedo (2012) obtained the factor Work Fulfillment as result in the top hierarchy. It is observed that all studies are consistent with respect to the factor of minor importance Prestige. Concluding that for all presumed audiences, fame, notoriety, competitiveness are less valued than stability, achievement at work and social relations.

For Schwartz (2006), the hierarchy of values is formed during the life of the individual, they are transsituational goals. For the author, the values demonstrate lasting and stable characteristics, but the priority can be changed due to the circumstances of life.

Through the Mann-Whitney test, the significance of the mean differences of the groups was prsented, considering the highly significant results $p<0.001$ and significant $p<0.05$. The hypotheses were included: $\mathrm{HO}=$ the average number of the groups are equal for $p>0.05$ and $\mathrm{H} 1=$ the average numbers of the groups are different when for $p<0.05$, considering Group 1: Total of researched that never worked; Group 2: Feminine and masculine genres; Group 3: Administration and Accounting courses; Group 4: Pharmacy and Physiotherapy courses: Group 5: Business Management and Health areas, according to table 10:

Table 10

Significance of work-related values between groups

\begin{tabular}{|c|c|c|c|c|c|c|}
\hline & $\begin{array}{l}\text { Factor } 1 \\
\text { Fulfillmen } \\
\mathrm{t} \text { at work }\end{array}$ & $\begin{array}{l}\text { Factor } 2 \\
\text { Social } \\
\text { Relationshi } \\
\text { ps }\end{array}$ & $\begin{array}{l}\text { Factor } 3 \\
\text { Prestige }\end{array}$ & $\begin{array}{l}\text { Factor } 4 \\
\text { Stability }\end{array}$ & Hypotheses & Conclusion \\
\hline Value of $p$ Group 1 & 0,866 & 0,823 & 0,554 & 0,659 & $\begin{array}{l}\mathrm{H} 0=\text { equal average in } \\
\text { the group } \\
\mathrm{H} 1=\text { different average } \\
\text { in the group }\end{array}$ & $\begin{array}{l}\mathrm{HO} \text { is accepted (null } \\
\text { hypothesis) } \\
\text { For all factors }\end{array}$ \\
\hline Value of $p$ Group 2 & 0,912 & 0,937 & 0,001 & 0,881 & $\begin{array}{l}\mathrm{H} 0 \text { = equal average in } \\
\text { the group } \\
\mathrm{H} 1=\text { different average } \\
\text { in the group }\end{array}$ & $\begin{array}{l}\text { Reject } \mathrm{HO} \text { for factor } 3 \text {. } \\
\text { Accept HO for the } \\
\text { other factors }\end{array}$ \\
\hline Value of $p$ Group 3 & 0,412 & 0,308 & 0,001 & 0,824 & $\begin{array}{l}\mathrm{H} 0=\text { equal average in } \\
\text { the group } \\
\mathrm{H} 1=\text { different average } \\
\text { in the group }\end{array}$ & $\begin{array}{l}\text { Reject } \mathrm{HO} \text { for factor } 3 . \\
\text { Accept HO for the } \\
\text { other factors }\end{array}$ \\
\hline $\begin{array}{l}\text { Value of } p \\
\text { Group } 4\end{array}$ & 0,016 & 0,040 & 0,109 & 0,653 & $\begin{array}{l}\mathrm{H} 0 \text { = equal average in } \\
\text { the group } \\
\mathrm{H} 1=\text { different average } \\
\text { in the group }\end{array}$ & $\begin{array}{l}\text { Reject } \mathrm{HO} \text { for factors } \\
1,2 \text { and } 3 \text {. Accept HO } \\
\text { for factor } 4 \text {. }\end{array}$ \\
\hline Value of $p$ Group 5 & 0,490 & 0,057 & 0,004 & 0,157 & $\begin{array}{l}\mathrm{H} 0=\text { equal average in } \\
\text { the group } \\
\mathrm{H} 1=\text { different average } \\
\text { in the group }\end{array}$ & $\begin{array}{l}\text { Reject } \mathrm{HO} \text { for factor } 3 . \\
\text { Accept HO for the } \\
\text { other factors }\end{array}$ \\
\hline
\end{tabular}

The hypotheses: $\mathrm{H} 0=$ the averages of the groups are equal for $\mathrm{p}>0.05$ and $\mathrm{H} 1=$ the averages of the groups are different when for $\mathrm{p}$ $<0,05$. Results highly significant $p \leq 0.001$ and significant $p \leq 0.05$.

Group 1: Total of researched and researched who never worked;

Group 2: Feminine and masculine gender;

Group 3: Administration and Accounting courses; 
Group 4: Pharmacy and Physiotherapy courses:

Group 5: Business Management and Health Areas

Source: Own authors (2018)

For in-depth analysis of the hypotheses besides the significance test, the average numbers of the 5 groups in table 11 are also compared:

Table 11

Average of EVT factors by area, course, gender, and experience in the work market

\begin{tabular}{|c|c|c|c|c|c|}
\hline & Freq. & $\begin{array}{c}\text { Realization } \\
\text { At work }\end{array}$ & $\begin{array}{c}\text { Social } \\
\text { Relationships }\end{array}$ & Prestige & Stability \\
\hline \multicolumn{6}{|l|}{ Group1 } \\
\hline Overall average & 335 & 4,04 & 3,72 & 3,19 & 4,33 \\
\hline Standard deviation & & 0,566 & 0,688 & 0,732 & 0,547 \\
\hline Never worked & 52 & 4,05 & 3,74 & 3,13 & 4,30 \\
\hline Standard deviation & & 0,59 & 0,72 & 0,76 & 0,59 \\
\hline \multicolumn{6}{|l|}{ Group 2} \\
\hline Female & 238 & 4,04 & 3,72 & 3,05 & 4,32 \\
\hline Standard deviation & & 0,575 & 0,676 & 0,707 & 0,563 \\
\hline Male & 97 & 4,05 & 3,71 & 3,51 & 4,34 \\
\hline Standard deviation & & 0,547 & 0,722 & 0,692 & 0,508 \\
\hline \multicolumn{6}{|l|}{ Group 3} \\
\hline Administration & 100 & 4,05 & 3,69 & 3,47 & 4,33 \\
\hline Standard deviation & & 0,591 & 0,753 & 0,712 & 0,63 \\
\hline Accounting Science & 131 & 4,01 & 3,64 & 3,10 & 4,36 \\
\hline Standard deviation & & 0,532 & 0,691 & 0,713 & 0,513 \\
\hline \multicolumn{6}{|l|}{ Group 4} \\
\hline Pharmacy & 42 & 4,25 & 4,04 & 3,15 & 4,26 \\
\hline Standard deviation & & 0,528 & 0,524 & 0,674 & 0,409 \\
\hline Physiotherapy & 62 & 3,95 & 3,71 & 2,94 & 4,3 \\
\hline Standard deviation & & 0,65 & 0,621 & 0,723 & 0,52 \\
\hline \multicolumn{6}{|l|}{ Group 5} \\
\hline Business courses & 231 & 4,03 & 3,67 & 3,27 & 4,34 \\
\hline Standard deviation & & 0,56 & 0,72 & 0,73 & 0,57 \\
\hline Health care courses & 104 & 4,07 & 3,84 & 3,02 & 4,39 \\
\hline Standard deviation & & 0,59 & 0,60 & 0,71 & 0,51 \\
\hline
\end{tabular}

Source: Own authors (2018)

The results presented did not support the hypothesis of this study that predicted differences in the hierarchy of work values between the areas of health and business management. As presented in group 5, the hierarchy is the same for both areas. It can be noted in the comparison of the average numbers that the hierarchy is equal and the similar means between group 1, composed of the total of those surveyed and those who have never worked. In this group, all factors obtained p-value> 0.05 , showing that even individuals who did not start a professional career have similar work values to the other groups.

Indeed, it is observed that regardless of gender, course, period, work area, whether someone works or never worked, the hierarchy of professional values obtained the same order of priorities, starting with Stability, followed by Achievement at Work, Social Relations and Prestige.

Some variables showed some alterations, a significant $p$-value significance of group $2 \leq 0.001$ was observed between the means of the two genders in the prestige factor, the number for the female group was (3.05 with $d v 0.707)$ and for the male group (3.51 with $d v 0.692)$, concluding that male students value more autonomy, 
professional success and influence power in the work. This result is similar to the study of Campos and Teixeira (2007).

The comparison of the averages of the prestige factor between group 3, courses in the area of business management (administration and accounting sciences) shows a high significance p-value group $3 \leq 0.001$, which presents the averages 3.47 ( $d v 0.712$ ) and 3.10 ( $d v 0.713$ ) respectively, concluding that future managers value the prestige factor more than accountants.

For group 4, the significant differences $p$-value group $4<0.05$ for the courses of the health area (pharmacy and physiotherapy) were in the work performance factors with 4.25 (dv 0.528 ) and 3.95 (dv 0.650) And social relations with averages 4.04 ( $d v 0.524$ ) and 3.71 ( $d v 0.621$ ). It is noticed that the students of the physiotherapy value less than the future pharmacists the achievement to the work that is represented by independence of thought, the enjoyment of the work and the social relations that cover relationship with colleague and society.

There is a significant difference in group 5 between the managerial and health areas, comparing the means of the EVT factors, a significant difference was observed in the prestige factor $p<0.05$ with averages $3,27(d v 0,73)$ and 3,02 (dv 0.71), reinforcing that the business management courses give greater importance to status, success, competitiveness and professional prominence. The stability factor has similar valuation for the four courses.

For Paschoal and Tamayo (2005, p 177, our translation) there is "the possibility that the values of work have a relevant predictive role in the process of professional choice. The individual assesses what profession or job represents an opportunity to achieve the goals that he or she deems relevant." In order to understand the 10 most important values for each of the areas, table 12 is presented, with the results of the business management area.

Table 12

Priority values for business area

\begin{tabular}{l|c|c}
\hline Values & Average & Factors \\
\hline Have better living conditions & 4.59 & Stabilty \\
To support myself & 4.55 & Stability \\
Professional achievement & 4.47 & Fulfillment at work \\
Earn money & 4.45 & Stability \\
Financial stability & 4.44 & Stability \\
Personal realization & 4.39 & Fulfillment at work \\
To be financially independente & 4.39 & Stability \\
To be content with the work I do & 4.38 & Fulfillment at work \\
Enjoy what I do & 4.38 & Fulfillment at work \\
Improve knowledge in my profession & 4.33 & Fulfillment at work \\
\hline
\end{tabular}

Source: Own authors (2018)

It is perceived that the value with the highest average of 4.59 is the search for better living conditions and other values such as "Being happy with the work I do and taking pleasure in what I do". According to Pedroso Et al. (2014b) since the industrial revolution, workers have started to demand shorter working hours and better working conditions. The concern with health and well-being at work is part of the strategies to keep employees satisfied.

It can be noticed that 5 priority values are related to the Stability factor and 5 values referring to the Fulfillment factor in the work. This public will seek work opportunities in which they can first promote financial security and 
better living conditions, followed by work in which can promote satisfaction in the accomplishment that is significant that brings about professional achievement. These are the factors that they value in the professional environment. This result is divergent from the non-academic literature, which presents the youth's greater interest in challenging work, learning, creating and innovating before financial stability.

Table 13 presents the 10 priority values for health area:

Table 13

Prioritized values in the area of Healthcare

\begin{tabular}{l|c|c}
\hline Values & Average & Factors \\
\hline Have better living conditions & 4.50 & Stability \\
\hline Be content with the work I do & 4.47 & Fulfillment at work \\
\hline Enjoy what I do & 4.47 & Fulfillment at work \\
\hline Improve knowledge in my profession & 4.45 & Fulfillment at work \\
\hline Enjoy what I do & 4.45 & Fulfillment at work \\
\hline To support myself financially & 4.44 & Stability \\
\hline Personal satisfaction & 4.38 & Fulfillment at work \\
\hline Financial Stability & 4.38 & Stability \\
\hline Earn Money & 4.36 & Stability \\
\hline Personal realization & 4.33 & Fulfillment at work \\
\hline
\end{tabular}

Source: Own authors (2018)

It is noted again that the stability factor was strong with the value at the top of the hierarchy, in the health area there were 4 values related to the Stability factor and 6 factors related to the factor Achievement in the work. The group presented a slightly higher mean in both factors than the business management area but maintained the hierarchy starting with Stability 4.37 and then Achievement in Work with 4.07 . It is noticed that 8 of the 10 priority values are equal to the two groups, which shows similarity of interest of the groups.

For Reis Et al.. (2010, p.33, our translation) "one aspect that has received research attention is to understand to what extent a person's values undergo changes over time, at different stages of his life and / or career." Paschoal and Tamayo (2005) emphasize that stability increases as labor market experience increases.

In order to test the hypothesis that there is a difference in values priorities according to differences in sociodemographic profiles, we used the classification of correlations ( $p$ Spearman) according to the theory of Dancey and Reidy (2013) in order to differentiate strong, moderate or weak relationships, shown in Table 14:

Table 14

Classification of significance of correlations

\begin{tabular}{c|c|c|c}
\hline Strong & Moderate & Weak & Nonexistent \\
\hline 1 to 0.7 & 0,6 to 0.4 & 0.1 to 0.3 & 0 \\
\hline \multicolumn{4}{c}{ Source: Dancey \& Reidy (2013) }
\end{tabular}

The variable that presented a weak positive correlation ( $p$ Spearman) of ( 0.124 with $p$-value of 0.036 ) was the time of labor market experience, i.e., the higher the experience time, the greater the importance attributed to the stability factor. The result excluded the sample of the respondents who never worked to better understand the factor averages in table 15. 
Table 15

Comparison of averages in the factor stability $\mathrm{x}$ time in the market

\begin{tabular}{c|c|c}
\hline Time in the Market & Frequency & $\begin{array}{c}\text { Average } \\
\text { Stability }\end{array}$ \\
\hline Up to 1 year & 25 & 4.18 \\
Between 1 and 3 years & 69 & 4.25 \\
Between 3 and 5 years & 57 & 4.36 \\
More then 5 years & 132 & 4.39
\end{tabular}

Positive weak correlation ( $p$ Spearman) of (0.124 with p-value of 0.036$)$

Source: Own authors (2018)

The result is similar to that published by Estivalete Et al. (2009) that with the passage of time of professional experience the individual searches more for stability. The similarity found between the studies gives more support to this research.

Another variable of the sociodemographic profile that presented a relationship with the factors of the EVT was family income, with ( $p$ Spearman) a weak positive correlation $(0.120$ with $p \leq 0.05)$ with the prestige factor and a weak positive correlation $(0.117$ with $p \leq 005)$ with stability factor. The result shows that as the family income of those surveyed increases, the greater is the search for prestige and stability.

The correlation analysis ( $p$ Spearman) of the 4 factors in the validation of the original instrument developed by Porto and Tamayo (2003) showed a strong correlation between the factors at work and social relations (0.54) and among the other factors, weak correlation, according to table 16.

Table 16

Correlation of the validation of the original instrument

\begin{tabular}{c|c|c|c|c}
\hline Correlation & $\begin{array}{c}\text { Fulfillment } \\
\text { at work }\end{array}$ & $\begin{array}{c}\text { Social } \\
\text { Relationships }\end{array}$ & Prestige & Stability \\
\hline Fulfillment at work & & 0,54 & 0,37 & 0,21 \\
Social relationships & & & 0,20 & 0,08 \\
Prestige & & & 0,39 \\
\hline
\end{tabular}

Source: Porto \& Tamayo (2003).

In comparison, the correlation analysis ( $p$ Spearman) of this research, in order to find out if there is any relationship, which direction, strength and significance of these, is presented in table 17:

Table 17

Correlation of factors in present research (p) Spearman

\begin{tabular}{c|c|c|c|c}
\hline Correlations & $\begin{array}{c}\text { Fulfillment } \\
\text { at work }\end{array}$ & $\begin{array}{c}\text { Social } \\
\text { Relationships }\end{array}$ & Prestige & Stability \\
\hline Fulfillment at work & & $0,76 * * *$ & $0,58 * * *$ & $0,49 * * *$ \\
Social relationships & & & $0,53 * * *$ & $0,37 * * *$ \\
\multicolumn{2}{c}{ Prestige } & & & $0,49 * * *$ \\
\hline
\end{tabular}

Source: Own authors (2018)

According to the classification of the results of the correlation ( $p$ Spearman) presented by Dancey and Reidy (2013), the correlations of table 13 present a strong positive correlation for work achievement and social relations, 0.76 with high significance $p \leq 0.001$. It is strongly concluded that when the achievement factor increases at work, the social relations factor increases. The achievement factors in the work and social relations showed moderate correlation with the prestige factor. The achievement factors in the work and prestige present 
moderate correlation with stability, evidencing that as the search for achievement in the work increases and prestige also increases the search for stability and the factor social relations weak correlation with stability, all correlations are positive with high significance $p \leq 0.001$.

\section{Conclusions}

The results show that the main objective of the study was achieved by highlighting the main values that guide young people in both areas (business and health) to work. 4 courses were studied, 4 periods in each course, 2 genders, several families, income brackets, the study concludes that all groups have the same sequence hierarchy, evidencing the preference for stability, following performance at work, social relationships and finally prestige.

The results presented by the present research did not support the first hypothesis that the two areas would have different work values. The second hypothesis was that the socio-demographic profile differences would present different priority values. At this point, the results comparing the different profiles showed the same hierarchy, that is, the same order of values, but some with more and less intensity than others according to the variables gender, labor market experience and family income. In this case, the hypothesis was tested and the study concluded that students with greater work experience value more the stability factor, those with higher family income value more for prestige and stability.

Despite these contributions, it is worth mentioning some limitations of the study. The first one refers to the sample that was composed only of 4 courses, two areas, suggesting that the study be replicated using more courses. The other limitation is the age range, time in the small job market considering that the study analyzed only students from the two areas and these in the vast majority have similar characteristics in these points. It is suggested to replicate the study by increasing the time of experience in the labor market and age using as sample trained professionals in these areas of several years to compare with a larger range of time, age and other sociodemographic variables.

\section{Bibliographic References}

Almeida S.T., Camara, S.M. A, Leone, N.M.C, \& Gurgel, F.F. (2015). Análise Estatística dos valores relativos ao trabalho e o comprometimento organizacional. CONEXXIO. Revista Científica da Escola de Gestão e Negócios. 4 (2), 123-139.

Calvosa, M. V. D. (2012). Uma Pesquisa Bibliométrica sobre Valores Pessoas: a análise global de instrumentos de mensuração de valores pessoais. In: XXVII Simpósio de Gestão da Inovação Tecnológica. Anais APAD. Salvador (BA) 1-16.

Cammarosano, M.; Santos, F. C. A; Rojas, F.A.R. (2014). Valores Relativos ao Trabalho de Pesquisadores em uma Organização de Pesquisa e Desenvolvimento Brasileira. Revista de Administração de Empresas. São Paulo. 54 (4), 445-457. DOI: http://dx.doi.org/10.1590/S0034-75902014

Campos, B. A. Teixeira, M.L.M. (2007). Valores Relativos ao Trabalho: um estudo em empresas juniores. In: EnGPR 2007, I Encontro de Gestão de Pessoas e Relações do Trabalho. Anais ... Natal: 1-15

Dancey, C. P.; Reidy, J. (2013). Estatística Sem Matemática para Psicologia: usando SPSS para Windows. 5. ed. Porto Alegre: Artmed.

Dias, R. S. (2012). O Assédio Moral e a sua Influência na Hierarquia de Valores do Trabalho. 137f.. Master's thesis (Human Resources Management and Organizational Analysis, Scientific Area of Organizational Analysis). Faculdade de Ciências da Economia e da Empresa. Universidade Lusíada de Lisboa, Lisboa. 
Esteves, M. (2008). Valores Individuais e Valores Relativos ao Trabalho: estudo dos norteadores da atuação de profissionais de recursos humanos. 114f. Master's thesis (Business Administration). Faculdade Novos Horizontes, Belo Horizonte.

Estivalete, V. F. B; Lobler, M. L.; Visentini, M. M. S. (2009). Valores Relativos ao Trabalho e sua Relação com o Comprometimento Organizacional: a percepção dos colaboradores de uma empresa internacionalizada. In: l'IFBAE France. Anais ... Grenoble, 1-18.

Gahan, P.; Abeysekera, L. (2009). What shapes an individual's work values? An integrated model of the relationship between work values, national culture and self-construal, International Journal of Human Resource Management, 20 (1), 126-147, http://dx.doi.org/10.1080/09585190802528524

Gil, A. C. (2008). Como Elaborar Projetos de Pesquisa. 4. ed. São Paulo: Atlas.

Góes, A. M. M. (2006). Valores Relativos ao Trabalho como Antecedentes do Comprometimento Organizacional. 71f. Master's thesis (Psychology). Post-Graduation Program in Psychology. Universidade Católica de Brasília. Brasília.

Hirschi, A. (2010). Positive adolescent career development: The role of intrinsic and extrinsic work values, Career Development Quarterly, 58 (1), 276-287. DOI: 10.1002/j.2161-0045.2010.tb00193.x

Kamia, M., Porto, J. B. (2011). Comportamento proativo nas organizações: o efeito dos valores pessoais. Psicologia: ciência e profissão. 31 (3), 456-467.

Knafo, A., Roccas, S., Sagiv, L. (2011) .The Value of Values in Cross-Cultural Research: A Special Issue in Honor of Shalom Schwartz. Journal of Cross-Cultural Psychology, 42 (2), 178-185.

Latifi, F. (2006). A dynamic model interpreting work-related values of multi-faceted cultures: The case of Iran, International Journal of Human Resource Management, 17 (12) 2055-2073, http://dx.doi.org/10.1080/09585190601000188

Lievore, C.; Picinin, C. T.; Pilatti, L. A. (2017) Fields of knowledge in graduate courses in Brazil: Longitudinal growth from 1995 to 2014. Ensaio: Avaliação e Políticas Públicas em Educação, vol.25, n.94, pp.207237. Doi.org/10.1590/s0104-40362017000100008.

Maccoby, M. (2006). Is There a best way to lead scientists and engineers? Research Technology Management, 49 (1), 60-61. http://dx.doi.org/10.1590/S1415-65552010000300008

Macedo, K.C. (2012). Valores Profissionais da Geração Y: um estudo sobre a Geração Y e os princípios orientadores em sua vida no trabalho. 2012. 44f.. (Bachelor Thesis) Universidade Federal do Rio Grande do Sul, Porto Alegre.

Paschoal, T.; Tamayo, A. (2005). Impacto dos valores laborais e da interferência família-trabalho no estresse ocupacional. Psicologia: Teoria e Pesquisa, Brasília. 21 (2), 173-180.

Pasquali, L., Alves, A. (2004). Validação do Portraits Questionnaire - PQ de Schwartz para o Brasil. Avaliação Psicológica. 3 (2), 73-82.

Pedroso, B. Pilatti, L.A.; Gutierrez, G.L.; Picinin, C. T. (2014b) Construction and validation of TQWL-42: A quality of work life measurement instrument. Revista de Salud Pública, vol. 16, n. 6, diciembre, pp. 885-896 Doi.org/10.15446/rsap.v16n6.30224 
Pedroso, B.; Kovaleski, A.; Ferreira, C.L.; Pilatti, L.A.; Gutierrez, G.L.; Picinin, C.T. (2014a) Desenvolvimento e validação da versão brasileira do Diagnóstico do Trabalho (Job Diagnostic Survey) de Hackman e Oldham. Gestão e Produção [online]. vol.21, n.2, pp.285-301. Doi.org/10.1590/0104-530X198.

Portal Brasil (2015). Educação - Mulheres são maioria no ingresso e na conclusão de cursos superiores. Available under http://www.brasil.gov.br/educacao/2015/03/mulheres-sao-maioria-no-ingresso-e-na-conclusao-decursos-superiores

Porto J. B., Tamayo, A. (2007). Estrutura dos Valores Pessoais: A Relação entre Valores Gerais e Laborais. Psicologia: Teoria e Pesquisa, Brasília. 23 (1), 63-70.

Porto J. B., Tamayo, A. (2008). Valores do trabalho. In: SIQUEIRA, M. M. M. Medidas do Comportamento Organizacional: Ferramentas de diagnóstico e de gestão. Porto Alegre: Artmed. Cap 19. Valores do Trabalho. 295-307.

Porto, J. B. (1998). Prioridades axiológicas e culturas regionais como preditores de civismo nas organizações. 115 f.. Master's thesis (Social and Work Psychology) - Instituto de Psicologia, Universidade de Brasília, Brasília.

Porto, J. B., Tamayo, A. (2003). Escala de Valores do Trabalho: EVT. Psicologia: Teoria e Pesquisa, Brasília, 19 (2), 145-152.

Reis, G. G., Antonio, F. A. A., Santos, A. L., Marinho, B. L. (2010). Os Valores de Administradores de Empresas mudam ao longo da carreira? Relações entre Prioridades Axiológicas e Tempo de Formado. Ram, Ver. Adm. Mackenzie. 11 (5), 32-54.

Rohan, M. J. (2000). A rose by any name? The values construct. Personality and Social Psychology Review, 4 (3). 255-277. doi: 10.1207/S15327957PSPR0403_4

Rokeach, M. (1973). The Nature of Values. Free Press.

Rokeach, M. (1974). Change and stability in American Value Systems, 1968-1971. Public Opinion Quarterly. 38, 222-238.

Ros, M. (2006). Psicologia social dos valores: uma perspectiva histórica. In: Ros, M.; Gouveia, V. V. [org.] Psicologia social dos valores humanos - Desenvolvimentos teóricos, metodológicos e aplicados. São Paulo: SENAC. 23-53

Ros, M., Schwartz, S. H., Surkiss, S. (1999). Basic individual values, work values and the meaning of work. Applied Psychology: An International Review, 48, 49-71.

Santos, C.B.; Pedroso, B.; Guimarães, A.M.; Carvalho, D.R.; Pilatti, L. A. (2017) Forecasting of Human Development Index of Latin American Countries Through Data Mining Techniques. IEEE Latin America Transactions,. vol. 15. n.9, september, pp. 1747-1753 Doi: 10.1109/TLA.2017.8015082

Schwartz S. H., Bilsky, W. T. (1987). Toward a universal Psychological Structure of Human Values. Journal of Personality and Social Psychology. 53 (3), 550-562. http://dx.doi.org/10.1037/0022-3514.58.5.878

Schwartz, S. H. (1992). Universal in the content and structure of values: Theoretical advances and empirical test in 20 countries. In: ZANNA, M. P. [org.] Advances in Experimental Social Psychology, New York: Academic Press. 25, 1-65. 
Schwartz, S. H. (2006). Les valeurs de base de la personne: Theorie, mesures et applications. Revue française de sociologie, 47 (4), 929-968.

Schwartz, S. H. (2011). Studying Values: Personal Adventure, Future Directions. Journal of Cross-Cultural Psychology, 42 (2), 307-319 doi: 10.1177/0022022110396925

Tamayo, A. (2007). Hierarquia de valores transculturais e brasileiros. Psicologia: Teoria e Pesquisa, Brasília, 23 n. especial. 7-15 http://dx.doi.org/10.1590/S0102-37722007000500003.

Tamayo, A., Faria, J.B., Tavares, M.S.O.C. Carvalho, E.M.; Bertolini, V. (1998). Diferenças nas prioridades axiológicas de músicos e advogados. Psicologia: reflexão e crítica, 11 (2), 281-294. http://dx.doi.org/10.1590/S0102-79721998000200008.

Tamayo, A., Paschoal, T. (2003). A Relação da Motivação para o Trabalho com as Metas do Trabalhador. Revista de Administração Contemporânea RAC, 7 (4). 33-54 http://dx.doi.org/10.1590/S141565552003000400003

Triola, M. F. (1999). Introdução à estatística. 7. ed. Rio de Janeiro: LTC.

Esta obra está bajo una Licencia Creative Commons Attribución-NoCommercial 4.0 International

(c) EY-NG 